\title{
READING INDONESIAN AND MALAYSIAN YOUNG ADULT NOVELS: CAPTURING THE IMAGE OF YOUNG MUSLIM WOMEN IN INDONESIA AND MALAYSIA
}

\author{
Nor Ismah \\ Leiden University, n.ismah@,bum.leidenuniv.nl
}

(c) (1) (-)

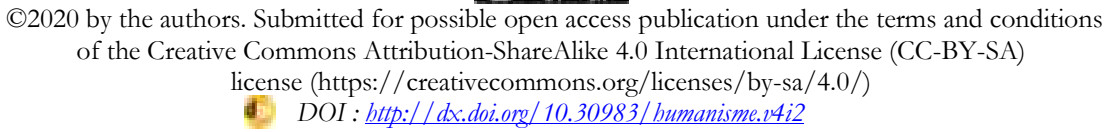

\begin{abstract}
A number of novel remaja, which mean young adult novels, written by women writers from Indonesia and Malaysia have been published. Writing competitions held by book publishers and language centers have also encouraged the production of the novels. However, since they address youth as their readers and tend to consider the characters, issues, language, and values that appeal to the modern young adult; therefore, some critics say that the novels only respond to the demands of the reader market and they are less creative and lack of quality. In this paper I demonstrate the value of Indonesian and Malaysian novel remaja by examining four novels which are Siti Zaleha M. Hashim's Biarkan Kupu-Kupu Terbang ("Let the Butterfly Fly"), Rumah Cinta Kelana ("The Love House of Kelana"), written by Sofie Dewayani, Nisah Haron's Mencari Locus Standi ("Finding the Defense Locus"), and Jadilah Purnamaku Ning written by Khilma Anis. I argue that those novels do not only explore young adults' feelings, including romance, fear, sadness, happiness, and challenges, but they also describe important themes which may inspire young readers, such as how young Muslim women deal with their identity formation, living in a single mother family, and polygamy.
\end{abstract}

Keywords: Young adult novels, Indonesia, Malaysia, Image of young Muslim women, Gender analysis

\begin{abstract}
Abstrak
Novel-novel remaja karya penulis perempuan banyak diterbitkean di Indonesia dan Malaysia. Lomba menulis yang diadakan oleh penerbit buku dan pusat bahasa juga mendorong banyaknya produksi novel-novel tersebut. Namun, karena novel remaja menyasar remaja sebagai pembacanya, novel tersebut ditulis dengan mempertimbangkan karakter, isu, bahasa, dan nilai-nilai yang menarik bagi remaja modern. Sebingga, beberapa kritikus mengatakan bahwa novel remaja hanya menjawab tuntutan pasar pembaca dan kurang kreatif serta berkualitas. Tulisan ini bertujuan untuk menunjukkan nilai positif novel remaja yang terbit di Indonesia dan Malaysia dengan menelaah empat novel. Yaitu, Biarkan Kupu-Kupu Terbang karya Siti Zaleha M. Hashim, Rumah Cinta Kelana yang ditulis oleh Sofie Dewayani, Mencari Locus Standi karya Nisah Haron, dan Jadilah Purnamaku Ning yang ditulis oleh Kbilma Anis. Saya berpendapat bahwa novel-novel tersebut tidak hanya mengeksplorasi perasaan remaja, termasuk percintaan, ketakutan, kesedihan, kebahagiaan, dan tantangan bidup, tetapi juga menggambarkan tema-tema penting yang dapat menginspirasi pembaca remaja. Misalnya, tema tentang bagaimana remaja Muslim perempuan menjalani proses pembentukan jati diri, bidup bersama keluarga dengan ibu tunggal, dan poligami, babkan juga mengkritisi ketimpangan posisi perempuan di dalam masyarakat.
\end{abstract}

Kata Kunci: Novel remaja, Indonesia, Malaysia, Citra remaja perempuan Muslim, Analisis gender 


\section{Introduction}

Images of women appear in numerous literary sources, ${ }^{1}$ but of particular interest are those in young adult novels that are directed toward young adults and are therefore written from their point of view. There are a number of young adult novels written by women from Indonesia and Malaysia, which are both Muslim countries, especially after 2000 when many teen novels emerged. Writing competitions held by book publishers, such as Mizan in Indonesia and the Malay Language Centers in Malaysia, have produced young adult novels. Now comprising their own genre, novel remaja (young adult novel), these novels deal with topics that have specific real Evince to a teenager's life, such as conflicts in love, in school relationships, and in the family. In the process, they explore the situation of women and female experiences.

Mahayana $^{2}$ considers novels are to be more appropriate genre than poetry or drama to explore the dynamics of a culture or society. It is because novels can better provide social representations, for instance, of

1 See Dian Swandayani \&Nuning Catur Sri Wilujeng, "Konstruksi Nilai-Nilai Perempuan Metropolis Indonesia dalam Majalah Femina", inJurnal Pendidikan Dan Kebudayaan, 16(5), p. 589-599, 2010; Ferli Hasanah. "Representasi Femme Fatale Dalam Novel Cantik Itu Luka Karya Eka Kurniawan", in Poetika, Vol 5, No 1, 2017; Yenni Hayati, "Dunia Perempuan dalam Karya Sastra Perempuan Indonesia (Kajian Feminisme)", in Humanis, Vol. XI No.1 Th. 2012.

'MamanMahayana, "The Oppressed Women: Discussion on the Development of Indonesian Women Novel and Its Comparison with the Malaysian and Indian Novels." Paper presented on ASEAN and India: Searching for New Approach arranged by Global Association of Indo-ASEAN Studies in Hankuk University of Foreign Studies, Seoul, South Korea, November 2-4, 2007. situations that involve current issues such as religious doctrines, norms, and even political power and the nature of government. However, as reported by Tasai, ${ }^{3}$ an Indonesian linguistic researcher, critics' forums such as a literary debate organized by National University Jakarta in 2005 have argued that this is not the case for young adult novels. This critics' forum claims that these novels deal with unimportant issues, mostly about personal experience that does not relate to social problems. Because the distinguishing characteristic of young adult novels is that they are written to consider the characters, issues, language, and values that appeal to the modern young adult; therefore, the novels tend only to respond to the demands of the reader market and they are less creative.

Nevertheless, I have read many young adult novels from Indonesia and Malaysia, and I have found that what critics think about young adult novels is not entirely true. Indeed, there may be some novels that fit the critics' representations, but there are others that I believe should be considered as novels of good quality. In this paper, I want to demonstrate the value of young adult novels. I argue that the representation of young Muslim women in both Indonesian and Malaysian young adult novels fosters ideas of gender equality. Young women in these novels are portrayed as independent people who make their own choices, not as stereotyped figures who are materialistic and focused only on themselves. Therefore, I contend that young adult novels can be a medium to communicate ideas about women and gender equality to young adult readers.

${ }^{3}$ M. Amran Tasai,"Teenlit, Masalah Baru Pernovelan Indonesia.” Republika, March 12, 2006. 
I will focus on four novels, two Indonesian and two Malaysian, published in the early 2000s. My intention to choose the early 2000's novels is to capture the specific period when the publication of novel remaja had just been flourished. The first novel is Rumah Cinta Kelana ("The Love House of Kelana") written by Sofie Dewayani and published in 2002. This novel won the 2002 novel-writing competition of Mizan, an Indonesian publishing company. The second is Khilma Anis's Jadilab Purnamaku Ning ("Be My Moon, Dear"), published in 2008, which explores the pesantren family life in Indonesia. I agree with Abidah el-Khaliqy, a prominent woman writer from the pesantren tradition, who endorses this novel as an attempt to respond to the publication of novels that refer to Islamic teaching but do not consider gender equality (Matapena 2008). Third, Mencari Locus Standi ("Finding the Defense Locus") was written by Nisah Haron and published in 2004. This novel won the Malay Language Centers' competition in Malaysia. Fourth, Siti Zaleha M. Hashim's Biarkan Кири-Kири Terbang ("Let the Butterfly Fly") was published in 2004 in Malaysia. This novel represents urban Muslims and attempts to build alternative opinions regarding the image of the stepmother, a role that is often perceived in novels as antagonistic.

The analysis of Indonesian and Malaysian young adult novels is significant in Southeast Asian studies as an attempt to understand the meaning of cultural production including print media in Muslim-majority countries in Southeast Asia. Bourdieu ${ }^{4}$ defines

4 Pierre Bourdieu, "Field of Power, Literary Field, and Habitus," in The Cultural Studies Reader Third cultural production as forms that "are produced in a particular social universe endowed with particular institutions and obeying specific laws." This means that print media, music, film, television, and any other cultural materials are considered to have distinguishing properties but they are associated with human thought and passion and a social universe that positions them as part of social culture. Young adult novels, specifically those that portray young Muslim women characters, can demonstrate that "popular Islam" signifies the emergence of a Muslim public sphere that has links to the use of new media in order to form young Muslim women's identity in Muslim-majority countries in Southeast Asia. Therefore, young adult novel is not just a form of modernization and popular culture but a medium to show the identity formation of young Muslim women. Thus, in Indonesia and Malaysia, popular culture and Islam have interconnections in defining the development of Muslim lives and practices in the Malay world.

This paper will present my reading and interpretation on those four novels. I will elaborate on identity formation, domestic relations, and gender inequality issues that I have found in the novels. I approach the novels with gender perspective. Latrobe

Edition, ed. Simon During, (New York: Routledge, 2007) p. 88-98.

${ }^{5}$ Andrew Weintraub pointed out that "the popular" in Islam refers to the regular everyday activities of people leading a Muslim life as regulated by the Qur'an, and therefore popular culture has now become a part of Islamization. Andrew Weintraub, "The Study of Islam and Popular Culture in Indonesia and Malaysia," in Islam and Popular Culture in Indonesia and Malaysia, ed. Andrew Weintraub (New York: Routledge, 2011), p.2-4. 
proposes three questions that should be considered in analyzing literary work through gender criticism, which are: "Does the character demonstrate independence (from gender expectations) in making decisions? If so, does the character pay the social price? [D]oes the character achieve acceptance from other characters and self?" My elaboration will be divided into four sub sections based on the four novels. My first elaboration is on Biarkan Кири-Кири Terbang, and it will be followed by Rumah Cinta Kelana, Mencari Locus Standi, and Jadilah Purnamaku, Ning. In conclusion, I will evaluate the similarities and differences between Indonesian and Malaysian young adult novels in terms of the images of young Muslim women in both countries.

\section{Izza Nafizah: A Malay Muslim Woman Teenager and the Stepmother Stereotype}

Biarkan Кири-Кири Terbang presents Izza

Nafisa as the main character. Although there is no information about her age, she is portrayed as a teenage high school student. ${ }^{7}$ In this novel, the plot employs a pattern in which a story begins from the middle and presents a significant incident. The story begins when Izza Nafisa finds out that her father is going to marry Salwa, a mother of a son. Although her biological mother passed away four years before, Izza Nafisa cannot accept a stepmother.

This starting story tells of a significant incident before reverting to an earlier period in the narrative, which is the story of how Izza

${ }^{6}$ Kathy Howard Latrobe and Judy Drury, Critical Approaches to Young Adult Literature (New York: NealSchuman, 2009), p.192.

${ }^{7}$ Siti Zaleha M Hashim, Biarkan Kupu-Kири Itu Terbang (Selangor, Malaysia: "K” Publications Sdn. Bhd., 2004) p.45. spent her time with her biological mother before the latter passed away. It shows how having a stepmother is a big problem for Izza as a teenager, therefore she attempts to keep a distance from her stepmother. Izza thinks that her stepmother will interfere her relationship with her father or even her father's feelings towards her biological mother. At the age when she is transforming from child to adolescent, she still has her childishness in which she actually depends on her mother's care. Therefore, she often remembers and feels nostalgic for the times she had with her mother and still does not accept her passing away. $^{8}$

In Erikson's psychosocial stages, ${ }^{9}$ the teen years to age $20+$, which correlates most to adolescence, are positioned at stage 5, a period when "identity" and "role confusion" are the most challenging for young people. He defines identity as "a movable crisis because forming an identity is a life-long crisis." Differences among ages and psychosocial stages affect people's characters, preoccupations, and tasks as individuals, members of a family, and society. Izza is still negotiating her emotional independence from adults, and she is a portrait that is intended to reflect the situation of young adults in general. Izza is characterized as reclusive (silent), but strong-minded, independent, smart, and making her own decisions. ${ }^{10}$ For example, regarding wearing tudung, ${ }^{11}$ it is explained, "Dia

\footnotetext{
'Ibid., p.14-15.

${ }^{9}$ Kathy Howard Latrobe and Judy Drury, Critical Approaches to Young Adult Literature...p.21.

${ }^{10}$ Siti Zaleha M Hashim, Biarkan Кири-Кири Itu..., p. 28,49

${ }^{11}$ Susan Blackburn explains that tudung is a "loose headscarf that does not tightly cover the hair." "Introduction" in Indonesian Islam in a New Era, edited
} 
akan memberontak jika dipaksa. Dia tidak suka dipaksa. Soal sembahyang, menutup aurat $^{2}$ merupakan sesuatu yang sangat pribadi. Itu antara dia dengan Tuhan". ${ }^{3}$

Besides her emotional condition, Izza's social environment is also important for her maturity development. Izza makes a friend with Shahira who always listens to her complaints, anger, and sadness. ${ }^{14}$ She also communicates with Affandi, Shahira's brother who lives in England, through email. ${ }^{15}$ In addition, Izza's involvement with the RamaRama Garden, a laboratory garden for butterfly conservation, gives her the opportunity to meet different people, such as those who work for and visit the garden. ${ }^{16}$ Socializing with males as well as females is also specifically described in the novel, in which defective.

Indeed, the description shows that Izza talks more often to her friends than to her father during her negotiations with herself as

by Susan Blackburn, Bianca J. Smith, and Siti Syamsiyatun (Victoria: Monash University Press, 2008), p. $x$.

${ }^{12}$ Aurat isconsidered as something that is shameful and defective so that other people should not see or hear like voice for women. There are different opinions regarding women's aurat on which part of their bodies are considered as aurat. See Nor Ismah, "Destabilising Male Domination: Building Community-Based Authority among Indonesian Female Ulama", Asian Studies Review, 40:4, 2016,p.493.

${ }^{13}$ She will revolt if her stepmother forces her. She does not like to be forced to do anything, including praying and covering her aurat. Praying and wearing a tudung is only between her and her God.” Siti Zaleha M Hashim, Biarkan Кири-Кири Itu.., p.28

${ }^{14}$ Ibid., p.4.

${ }^{15}$ Ibid., p.17.

${ }^{16}$ Ibid., p.2-3 she learns to accept her stepmother. But she finally opens her mind and, after a time, she finds that her stepmother truly loves her; moreover, she does not force Izza to wear tudung, but she does introduce Islamic lessons to Izza gradually. ${ }^{17}$ At this point, there are elements of Muslim identity formation that can be derived from the symbols in the novel, such as tudung, Al-Qur'an, and Islamic lessons. According to Meyer, ${ }^{18}$ a "symbol is a person, object, or event that suggests more than its literal meaning. "These symbols can be found in the novel at the point during which Izza is at the age of forming her identity. ${ }^{19}$ Another symbolic description in this novel is the importance of the national language, Malay, and how to use it properly in communication. ${ }^{20}$

Hereafter, Izza is very happy because her family is re-established. She has a father and a new mother whom she calls her "ibu" (mother), and she is thrilled, especially when she knows that her stepmother is pregnant and there will be a new baby in the family. The portrayal of the close relationship between Izza and her stepmother seems an attempt to counter common assumptions that a stepmother cannot behave like a biological mother. There is a stereotype of a woman as a stepmother that might be stereotyped as a demonic woman. Izza refers to Bawang Merah Bawang Putih (shallot and garlic) storytelling ${ }^{21}$ to illustrate her fear of being a stepchild.

To meet the expectations for the genre of young adult novels which is a happy

\footnotetext{
${ }^{17}$ Ibid., p.50.

${ }^{18}$ Ibid., p.173.

${ }^{19}$ Ibid., p.112

${ }^{20}$ Ibid., p.81-2

${ }^{21}$ Ibid., p.15
} 
ending, the story of Izza and her family ends happily. The novel title, Biarkan Кири-Кири Terbang implies the value of "reda" (or "ridho" in Indonesia, which means to be sincere), meaning "butterfly" is a symbol for feeling free. Izza's stepmother says, "Selain iman yang sempurna seorang mukmin musti reda dengan ketentuan Allah S.W.T. Dia berpuas hati dengan apa yang diperoleh, di samping memperbaiki keadaannya dan dia juga tidak berputus asa" ${ }^{22}$. This means that in order to accept reality no matter how bitter and hard it is, Izza should understand that everything is given by Allah, and as a good Muslim she should accept it.

\section{Kelana: An Urban Muslim Woman Teenager and the Second Wife Stereotype}

An image of "stepmother" is portrayed in the novel Rumah Cinta Kelana, but in more complicated manner compared to the story in the previous novel because she is a "second wife" through a non-certified marriage. The main character in this novel is Kelana, nicknamed Lana, a teenaged high school student who has just celebrated her sixteenth birthday. She has two sisters, Anggi, who is older, and Kori, who is younger, and a best friend named Andromeda. ${ }^{23}$ The story begins with the death of Lana's father. Lana is described as a self-willed person because she grew up in a family where her mother does not care what Lana says and does. Her mother only cares that Lana did her homework and

${ }^{22}$ "In addition to a comprehensive belief, a believer (mukmin) must be sincere toward what Allah s.w.t has decided. $\mathrm{He} /$ she must be satisfied with what he/she gets, andbesides he/she must improve his/her condition and never give up. Ibid., p.114.

${ }^{23}$ Sofie Dewayani, Rumah Cinta Kelana.(Bandung: Mizan, 2004)p.18, 58. got high grades in school. ${ }^{24}$ After the death of her father, she prefers to be by herself writing in her diary and avoiding meeting other people. Suddenly, she remembers a mysterious pregnant woman who came to her father's funeral, and the conflict then begins. ${ }^{25}$ According to Meyer, ${ }^{26}$ the "chronological arrangement," is a way of delivering a story in which 'the story starts from the part that happens first in time, and continues by keeping in the natural time sequence, and this is how Rumab Cinta Kelana is told.

Lana is curious to know about the woman who was at the funeral. As a daughter, Lana gets jealous because there is another woman who expressed her love for Lana's father and feels sad because of his death. ${ }^{27}$ In this crisis situation, Lana is struggling with these feelings. Referring to Robert Havighurst's list of developmental tasks, Lana is at the stage of "mature relations with agemates" and "emotional independence of adults", 28 and this crisis become an exercise that trains her to be mature. Lana gets used to thinking, contemplating, and deciding what she has to do without any assistance or help from her family. Furthermore, Lana trusts her friend more than her mother or her sisters. She shares her feelings with Andromeda, and even asks him to investigate the woman. ${ }^{29}$

In this novel, I found some symbols in the words and events. The way the author

${ }^{24}$ Ibid., p.18, 46.

${ }^{25}$ Ibid., p.18, 58

${ }^{26}$ Michael Meyer, The Bedford Introduction to Literature, (Boston: Bedford Books of St. Martin's Press, 1990), p.38.

${ }^{27}$ Sofie Dewayani, Rumah Cinta Kelana..., p.31.

${ }^{28}$ Kathy HowardLatrobe and Judy Drury,Critical Approaches..., p.16.

${ }^{29}$ Sofie Dewayani, Rumah Cinta Kelana..., p.58-9. 
portrays Evi as a second wife and through her conversations with Lana seems to counter the negative image of second wives. In Indonesia, there is a particular term used which is istri simpanan (secret wife). Istri simpanan is typically stereotyped as a family destroyer. Evi both feels and understands this stereotype, and therefore she says to Lana, "Apakah aku kelihatan seperti wanita jahat yang suka melihat orang lain sengsara, Lana? ... Apakah aku kelihatan seperti wanita pesolek yang suka memikat pria paruh baya yang sudah beristri, Lana?". 30

However, in this novel, the second wife is described as a pious woman with her jilbab, ${ }^{31}$ and even Lana comes to call her "Tante Cinta" (the auntie with the love), while Lana and her mother do not wear jilbab and the novel describes them as beginner Muslim. ${ }^{32}$ The way Lana's father meets Evi is described as well as something that is connected to the God will: "Dia-lah yang mempertemukan kami. Kami menikah tak berapa lama setelah itu",33 and "Pernikahan kami seperti pertemuan antara seorang pengembara dengan yang dicarinya. Jadi, tidak ada alasan untuk menceraikan Mamamu".34

30" Do you think that I look like someone so terrible that I would dare to hurt somebody else? Do I look like a crazy woman who obsesses to the point of stealing the husband of another woman?"'. Ibid., p.101.

31 Jilbab is a tied scarf that covers all of the hair, while kerudung is similar to tudung, which is an untied scarf that does not cover all of the hair. See Nancy Smith-Hefner, "Javanese Women and the Veil in PostSoehartoIndonesia". The Journal of Asian Studies, Vol. 66, No. 2 (May) 2007: p.389-420.

${ }^{32}$ Sofie Dewayani, Rumah Cinta Kelana..., p.164

${ }^{33} \mathrm{H} \mathrm{He}$ made us meet, and we got married afterward.' Ibid., p.144.

${ }^{34}$ 'Our marriage is like the meeting between the wanderer and someone whom he wanders. So, there
Moreover, after several visits, Lana feels more comfortable talking to Evi. She finally finds love and the caring environment that she misses at her own house. She calls Evi's house "Rumah Cinta" (the house of love) and her close relationship with Evi has cured her sadness, disappointment, and anger. ${ }^{35}$ Evi can understand Lana better than her own mother. Yet the author does not explore the feelings of Lana's mother as she does not know about her husband's second marriage. This situation is described from Evi's point of view and appears to condone polygamy, which many consider to be a practice that subordinates women. However, because young adult novels are told from a young adult perspective, they usually have a light discussion and the themes and dramatic images appeal to the emotions of young adults.

The presence of Evi's cares signifies an ideal family for Lana. This story shows how the ideal family, where somebody can find love, support, and attention, is very important in human development, especially for young adults and women. As stated by Belenky, ${ }^{36}$ women's ways of knowing are influenced by the family in which they grow up. From Evi, Lana learns how to be a good Muslim woman, as she also talks to Evi about shalat (praying) and the meaning of prayers. ${ }^{37}$ Thus, the dialog demonstrates the symbolization of being a good Muslim by conducting prayer and understanding the meaning of prayer.

was no reason to get a divorce from your mother.' Ibid., p.145.

${ }^{35}$ Ibid., p.141-147.

${ }^{36}$ Mary FieldBelenky, Blythe McVicker Clinchy, Nancy Rule Goldberger, and Jill Mattuck Tarule, Women's Ways of Knowing: The Development of Self, Voice, and Mind,(New York: Basic Books, 1986),p.156.

${ }^{37}$ Sofie Dewayani, Rumah Cinta Kelana..., p.150 
However, Evi does not suggest to Lana that she pray. She believes that she has no right to do so because, as a human being, Lana has a conscience that can guide her to her own right path. $^{38}$

Another symbolic description I found in this novel is that women characters are described as independent women who take responsibility according to what situation they are in. Without a husband, these mothers, Lana's mother and Evi who is pregnant, can handle the responsibility of taking care of their children and earning money. For example, Lana's mother continues her husband's business, while Evi is a painter. ${ }^{39}$ Lana is a responsible teenager as well. She struggles with traumatic loss, attempts to admit sorrows, and to move forward to have a happy life. Struggling through her personal maturity development, Lana learns how to understand what she thinks and wants without being persuaded by negative influences such as taking drugs and partying. She does not want to have sex before marriage and have an abortion like her elder sister did. ${ }^{40}$

Furthermore, how Lana finally has reached maturity can be seen at the end of the story. Unfortunately, Evi does not live long; she passes away when she delivers her baby. Lana decides to ask her mother to adopt the baby, and says she will explain about "Tante Cinta and Rumah Cinta" later. ${ }^{41}$ She is sad because of Evi's death, but she become more mature by accepting what happens in her life.

\footnotetext{
${ }^{38}$ Ibid., p.145, 149.

${ }^{39}$ Ibid., p.43, 144

40Ibid., p.94, 44

${ }^{41}$ Ibid., 163
}

\section{Eliza Jasmin:}

\section{A Malay Muslim Woman Young Adult and the Idea of Women and Education}

Like the two novels I have discussed, Mencari Locus Standi presents the image of a young Muslim woman. She is Eliza Jasmin, nicknamed E-Jay. In this Malaysian novel remaja, E-Jay is a student in the Law Department at the University of Kebangsaan Malaysia. She is 20 years old and is characterized as a strong-minded, assertive, wise, and independent person. ${ }^{42}$ This novel employs the chronological arrangement and flashbacks to narrate the plot, so that some of its stories start at the end and then are followed by an explanation of why or how the events happened. ${ }^{43}$ The author starts the story with an incident when E-Jay is attending her inauguration as a lawyer and after this the story moves on to relate how this incident came to pass. The story ends with the same incident. ${ }^{44}$

Living with adoptive parents, E-Jay feels much closer to her father, Emir, ${ }^{45}$ than to her mother. Her adoptive father has inspired her to be a lawyer and teaches her through his own legal experiences. Therefore, when he passed away, she feels that she has lost a major support in her life, and at the same time, family problems have emerged. The brothers of Emir claim that they have more right to get Emir's inheritance than E-Jay, according to faraid, which is an Islamic law that deals with inheritance distribution. However, E-Jay has rights as well regarding the inheritance

${ }^{42}$ Nisah Haron, Mencari Locus Standi, (Kuala Lumpur: Utusan, 2004) p.11, 12, 18, 51, 66.

${ }^{43}$ Michael Meyer, The Bedford Introduction, p.38

${ }^{44}$ Nisah Haron, Mencari Locus Standi..., p.xi, 238.

${ }^{45}$ Ibid., p. 51 
because Emir made a decision to allocate his property to E-Jay before his death. According to Islamic law, this decision is called wasiat. $^{46}$

Because her position in Emir's family has been doubted, E-Jay realizes that she needs to discover her true identity and her biological parents. ${ }^{47}$ Mustika, her adoptive mother, does not know anything because EJay came to Emir's family before her. Emir's first wife passed away in a car accident when E-Jay was small, and Emir married Mustika later. E-Jay feels much sadder because nobody can answer her questions now. In addition, EJay is also struggling with her studies and campus activities, including passing her examinations, her responsibility as a leader of a theater group preparing for a competition, and her problems in dealing with friendships and a love relationship. ${ }^{48}$

Indeed, as a young Muslim woman, EJay is an inspiring character. Although she is facing all these problems, she can maintain her focus and responsibility according to the role that she has to take in a certain situation. Among the students in the theater group, EJay is an idol and a perfect personality. She demonstrates her ability in leadership. She is also talented in screenplay writing and smart. But sometimes, as a young adult, E-Jay forgets to respect others' feelings. ${ }^{49}$ Her friend, Azhan Harits, accompanies her in discussion about obstacles and hopes and reminds her to be humble and wise..$^{50}$

Unlike Izza and Lana in their
relationships with boys as friends, the
${ }^{46}$ Ibid., p.141
${ }^{47}$ Ibid., p. 202
${ }^{48}$ Ibid., p. $32,37,86$.
${ }^{49}$ Ibid., p. 81
${ }^{50}$ Ibid., p. 211.

relationship between E-Jay and Azhan is more mature, as there is hidden love between them. E-Jay is in the period when she is preparing for career and marriage. After graduating, she wants to be a lawyer. In terms of marriage, EJay thinks that it is a big decision that requires deep thinking and consideration. She replies to Azhan Harits when he proposes: "Tapi aku fikir aku masih belum bersedia untuk keluar dari ruang keselesaan kita," balas E-Jay sambil tersenyum. "Tapi fikiranku mungkin berubah. Tanyakan aku semula bila kita tamat pengajian." 51 This is a very strong statement regarding women, achievement, and education. Therefore, E-Jay does not support Wardah when she wants to leave college in order to get married. ${ }^{52}$

With her potential and characters, E-Jay becomes a confident and persistent woman, and because of her persistence, she finally finds information about her biological parents. This is a long journey that brings E-Jay to meet her auntie, Mak Lang Rosmah, in a village, Sari Meranti, where Azhan's extended family also lives. Her biological mother passed away when she gave birth to E-Jay, while her biological father does not live in the village anymore, and nobody knows anything about him. But E-Jay believes that he is still alive. ${ }^{53}$ E-Jay is very happy with this finding because the connection to her biological parents is a primary aspect of her identity. Knowing her parents means that she knows her family adat (custom), that she must respect and follow. ${ }^{54}$

\footnotetext{
${ }^{51 ' B u t ~ I t h i n k ~ I ' m s t i l l n o t ~ r e a d y t o ~ g e t ~ o u t ~ o f o u r ~}$ comfortrelationship,' E-Jay answers with a smile.'Butmy thoughtsmay change.Askmeagainwhenwegraduate.'.” Ibid., p.112-3.

52Ibid., p. 215

53Ibid., p.203-206

${ }^{54}$ Ibid., p.70, 204
} 
In Mencari Locus Standi some descriptions show that local customs are more prioritized than cosmopolitan culture. In one incident, Farhanum is portrayed as a metropolitan young adult whereas Wardah represents a Malay young adult. There is a comparison between someone who has a cosmopolitan appearance (wearing a shirt with short sleeves and not wearing tudung), and someone who follows local customs, including wearing the tudung, which is considered a form of politeness. ${ }^{55}$ According to Cheng, ${ }^{56}$ most Malaysian Muslim young females in secondary school and universities were wearing the tudung by the late 1980s because the new Islam in the 1990s was scripturalist and Arabicinfluenced. This description shows that young female identity is very much influenced by the environment in which they live.

E-Jay's characterization as an independent young adult Muslim woman who follows Malay custom is clear in this novel. This demonstrates that these young adult novels are not just about love and friendship, but can be considered as a medium to connect young readers and local customs. Finally, EJay overcomes all of her obstacles successfully: her group becomes a winner in the competition, she defeats Emir's brothers over the family inheritance, she has a chance to meet her biological father in Melbourne, she finishes her studies, and she accepts Azhan Harits' marriage proposal. ${ }^{57}$ This overcoming of her obstacles demonstrates the theme of Mencari Locus Standi, which seems to be that

\footnotetext{
${ }^{55}$ Ibid., p.6

${ }^{56}$ Kho GaikCheng,Reclaiming Adat: Contemporary Malaysian Film and Literature, (Toronto: UBC Press, 2006), p.9. 236,245
}

life is tough, and consequently we must struggle to obtain happiness and success.

\section{Nawang Wulan: A Javanese Muslim Woman and Social Critic}

Nawang Wulan is the main character in Jadilab Purnamaku Ning that is at the age of preparing for a career and marriage. Sheis twenty years old and portrayed as a brave and independent Muslim woman. She wears jilbab (head scarf) and comes from a pesantren (Islamic boarding school) family. ${ }^{58}$ Her father is the son of a kiai (the founder and the leader of a pesantren), but Nawang never met him because her mother was divorced when she was pregnant with Nawang. The marriage of Nawang's parents broke up due to the intervention of her father's family who did not agree with the dedication with which Nawang's mother served the people who lived in the area surrounding the pesantren. In addition, her mother was rejected by her father's family due to her low status as she was not from a noble family. This divorce remains traumatic for Nawang's mother; therefore, she wants her daughter not to marry a man from a pesantren. ${ }^{59}$

However, Nawang has a love relationship with Alvin, a son of a prominent kiai in East Java. It is quite hard for Nawang to convince her mother that Alvin is not like her father. She is her mother's only daughter, so her mother does not want her having the same experience as she had. But Nawang is strong-minded and persistent. She says:

"Ibu tahu kan, kalau kulo, Nawang

Wulan Ibu, tak pernah diam dalam kondisi apa pun? Ibu juga kan

\footnotetext{
${ }^{58}$ Khilma Anis, Jadilah Purnamaku Ning,(Yogyakarta: Matapena, 2008), p.10, 20.

${ }^{59}$ Ibid.,p.9-11
} 
yang mengajarkan Nawang untuk melawan? Nawang manut pitutur Ibu. Hanya, beri Nawang kesempatan. Untuk sekadar memberikan kemenangan pada diri." $" 60$

Having Java and pesantren as settings, this novel is rich in languages and cultures. Nawang always use kulo to mean "I" when communicating with her mother. Kulo is krama madya in Javanese, which is used to communicate with elders and strangers in a respectful way. Furthermore, the combination of Javanese and pesantren is interesting, because both culture women are mostly not decision makers. Thus, the readers get a strong image of Nawang as an independent Javanese Muslim woman because she decides by herself whom she will marry. This is what Meyer means by the connection between setting and the overall objective of the story. The setting is the element of a literary work that explains the context, including place, time, and social environment, in which the action of a story happens. $^{61}$

The story then goes on to a scene when Alfin introduces Nawang to his family. Unfortunately, Nawang is facing the same experience that her mother had. Alvin's elite family rejects her because Alvin's father knows Nawang's mother very well, and is aware of the reason that her father rejected her mother. Although Nawang is described as an independent and brave woman, she feels

60"'Didn't you know, Ma, that I, your NawangWulan, will never be silent, in any case? Didn't you teach me how to fight? Nawang follows what you advise. However, give Nawang a chance in order to gain glory for myself."” Ibid.,p.17.

${ }^{61}$ Michael Meyer, The Bedford Introduction, p.107108. frustrated, and she needs the presence of a father as well to protect her and make her feel safe. ${ }^{62}$ But, in this condition, as she lives in a single-mother family, her mother takes responsibility as both mother and father for Nawang. Thus, this description shows that both Nawang and her mother are tough characters who can survive with their own strength.

The pesantren itself exercises constraints because it is considered a patriarchal community. According to Dhofier, ${ }^{63}$ the kiai is always a man and the only one who has power and authority in the pesantren. Nobody can oppose his authority, with the exception of another kiai who has wider power and authority, such as his father or teacher. In this case, Alfin's father has the authority. However, it is at this point that Yasfa emerges in the story, bringing Nawang a new hope: he is a humble person who loves Nawang the way she is. ${ }^{64}$ This description shows that her family's and friends' support are important for Nawang's personal development. One theme that I notice within the four novels I read is that all the main characters Izza, Lana, E-Jay and Nawang have the same challenge to embrace with the reality. Meanwhile, their families and friends appear as supportive people who influence the main characters' ways of forming their personality.

In terms of social relation, Nawang is portrayed as a young adult who has made a contribution to her community. First, Nawang is a leader in journalism and social activism

\footnotetext{
${ }^{62}$ Khilma Anis, Jadilah Purnamaku..., p.99

${ }^{63}$ ZamakhsyariDhofier,Tradisi Pesantren Studi Tentang Pandangan Hidup Kyai,(Jakarta: LP3ES, 1982), p.56

${ }^{64}$ Khilma Anis, Jadilah Purnamaku..., p.149
} 
including helping people in poverty. ${ }^{65}$ Second, Nawang represents her family, which is her mother, in defending their family's pride. She still attempts to defend her mother when Alfin's father despises her. ${ }^{66}$ Nawang commits to serving her community after marriage and she emphasizes her decision so that Alfin and Yasfa can understand her choice. ${ }^{67}$ Neither of them sees a barrier to creating their own gender roles in society. ${ }^{68}$

Nawang also criticizes the beauty myth produced by capitalism that drives women to compete to be seen as beautiful instead of to broaden their minds and knowledge. ${ }^{69}$ Nawang is born into Javanese culture. She feels and displays her Javanese roots to others by using some Javanese words and showing an interest in traditional Javanese wayang, or shadow puppetry. ${ }^{70}$ Furthermore, Jadilah Purnamaku Ning points out that the essence of Islam means that being a good Muslim requires not only having a close relationship with God through prayer and worship, but also behaving well and caring for other human beings. $^{71}$

The story in this novel demonstrates that gender relationships are changing and dynamic in Javanese and pesantren culture. This dynamic may be influenced by globalization and social transformation involving education and employment. Like many other cultures, Javanese cultureis also changing and developing because of the influence from interactions with other groups. Social change

\footnotetext{
${ }^{65}$ Ibid., p.22

66Ibid., p.91

${ }^{67}$ Ibid., p. 207

${ }^{68}$ Ibid., p.11

${ }^{69}$ Ibid., p. 130

${ }^{70}$ Ibid., p.49-50

${ }^{71}$ Ibid., p.11
}

is an ecessity because it reflects the culture as being dynamic due to cipta (creativity) and karsa (intention). ${ }^{72}$ Furthermore, the different male characters including Nawang's grandfather, Alfin's father, and Yasfa's adoptive father represent the different personalities among pesantren kiai, therefore we cannot generalize pesantren as a place that discourages gender equality. One example of this is Yasfa's adopted father, who is also a kiai. He is a humble person and supports his wife when she takes a public role by serving their community. ${ }^{73}$ For young readers who do not know about pesantren, this book may provide new knowledge about them, and this novel tries to connect pesantren and outsiders.

\section{Conclusion}

After reading and analyzing the four novels, I highlighted that Indonesian and Malaysian novel remaja employ the same aesthetic forms, narrative styles, and structures. What is most important about these novels is that they use a young adult perspective and present female young protagonists as the main characters. Compared with Izza and Kelana, E-Jay and Nawang make more connections with people from their local environment. According to Erikson, ${ }^{74}$ to be involved in a different subculture is important for teenagers because it is an influential way for youth to find out who they are. It can be said that when someone is responsive to the environment, it influences identity formation. The characters

\footnotetext{
${ }^{72}$ Berninghausen Jutta, and Birgit Kerstan,Forging New Paths: Feminist Social Methodology and Rural Women in Java,(London, Zed, 1992), p.32

${ }^{73}$ Khilma Anis, Jadilah Purnamaku..., p.187

${ }^{74}$ Kathy HowardLatrobe and Judy Drury,Critical Approaches to Young..., p.22
} 
analyzed in this paper are shown as protagonists whose images represent how Muslim young women's identities are formed with influences from the individual, the family, and the environment.

In terms of their themes and dramatic images, they follow the current trends and popular culture, but they also insist on their position and are critical toward some trends that are not congruent with their characters' identities, such as the use of language that mixes Malay and English and urban lifestyles. Those novels also explore young adults' feelings, including romance, fear, sadness, happiness, and challenges, as experienced by characters from different ethnic and cultural backgrounds, such as Malay, Javanese, and Islamic environments. Indeed, these four novels do have values that they seek to impart to their audiences. They all describe the young female character as an independent and responsive young Muslim woman, whose identity is formed by individual choices and is influenced by her family and environment. The most weight is given to the value of politeness, measured by local values, such as Malay and Javanese, and pesantren culture to be a good Muslim woman. From this limited sample, it appears that Malaysian novels have a broader imagination in regard to the variety of subcultures, which include Australia and London. This is not found in Indonesian young adult novels and obviously reflects the economic realities and opportunities for travel that prevail in the two societies.

There are similarities between these Indonesian and Malaysian novels in terms of gender-related themes, including stereotypes, which are presented in Rumah Cinta Kelana with the character of a second wife, and in
Biarkan Кири-Кири Terbang with the character of a stepmother. Subordinate women are also described in Rumah Cinta Kelana and Jadilah Purnamaku Ning, which are both Indonesian. Meanwhile, Mencari Locus Standi presents theidea of woman and education. Based on these depictions of young Muslim women, Indonesian and Malaysian young adult novels offer representations of gender equality. If these representations are effective, young adult novels' authors and young adult readers can both play an influential role in spreading ideas of gender equality.

\section{References}

\section{Books}

Anis, Khilma. Jadilab Purnamaku Ning. Yogyakarta: Matapena, 2008.

Belenky, Mary Field, Blythe McVicker Clinchy, Nancy Rule Goldberger, and Jill Mattuck Tarule. Women's Ways of Knowing: The Development of Self, Voice, and Mind. New York: Basic Books, 1986.

Jutta, Berninghausen and Birgit Kerstan. Forging New Paths: Feminist Social Methodology and Rural Women in Java. London, Zed, 1992.

Blackburn, Susan, Bianca J. Smith, and Siti Syamsiyatun. Indonesian Islam in a New Era: How Women Negotiate Their Muslim Identities. Monash Papers on Southeast Asia. Clayton, Victoria, Australia: Monash University Press, 2008.

Bourdieu, Pierre. "Field of Power, Literary Field, and Habitus." In The Cultural Studies Reader Third Edition, ed. Simon During, 88-98. New York: Routledge, 2007. 
Cheng, Kho Gaik. Reclaiming Adat: Contemporary Malaysian Film and Literature. Toronto: UBC Press, 2006.

Dewayani, Sofie. Rumah Cinta Kelana.Bandung: Mizan, 2004.

Dhofier, Zamakhsyari. Tradisi Pesantren Studi Tentang Pandangan Hidup Kyai. Jakarta: LP3ES, 1982.

Haron, Nisah. Mencari Locus Standi. Kuala Lumpur: Utusan, 2004.

Hashim, Siti Zaleha M. Biarkan Кири-Кири Itu Terbang. Selangor, Malaysia: "K" Publications Sdn. Bhd., 2004.

Latrobe, Kathy Howard, and Judy Drury. Critical Approaches to Young Adult Literature. New York: Neal-Schuman, 2009.

Meyer, Michael. The Bedford Introduction to Literature. Boston: Bedford Books of St. Martin's Press, 1990.

Weintraub, Andrew. "The Study of Islam and Popular Culture in Indonesia and Malaysia." In Islam and Popular Culture in Indonesia and Malaysia, edited by Andrew Weintraub, 1-17. New York: Routledge, 2011.

\section{Journals}

Hasanah, Ferli. "Representasi Femme Fatale Dalam Novel Cantik Itu Luka Karya Eka Kurniawan". In Poetika, Vol 5, No 1, 2017.

Hayati, Yenni. Dunia Perempuan dalam Karya Sastra Perempuan Indonesia(Kajian Feminisme). In Humanis, Vol. XI No.1 Th. 2012

Ismah, Nor. "Destabilising Male Domination: Building Community-Based Authority among Indonesian Female Ulama", Asian Studies Review, 40:4, 2016, p.491509
Smith-Hefner, Nancy J. "Javanese Women and the Veil in PostSoehartoIndonesia". The Journal of Asian Studies Vol. 66, No. 2 (May) 2007: 389-420

\section{Report, news and interview}

Mahayana, Maman. "The Oppressed Women: Discussion on the Development of Indonesian Women Novel and Its Comparison with the Malaysian and Indian Novels." Paper presented on ASE AN and India: Searching for New Approach arranged by Global Association of Indo-ASEAN Studies in Hankuk University of Foreign Studies, Seoul, South Korea, November 2-4, 2007.

Roberts, Rosemary, and Helen Creese. "Gender, Text, Performance and Agency in Asian Cultural Contexts." Intersections: Gender and Sexuality in Asia and the Pacific 16, March (2008).

Swandayani, D., \& Wilujeng, N. C. S. (2010). Konstruksi Nilai-Nilai Perempuan Metropolis Indonesia Dalam Majalah Femina. Jurnal Pendidikan Dan Kebudayaan, 16(5), 589-599

Tasai, M. Amran. "Teenlit, Masalah Baru Pernovelan Indonesia." Republika, March 12, 2006. 